\title{
BASIS EPISTEMOLOGIS PARADIGMA RASIONAL DALAM ILMU HUKUM: Sebuah Deskripsi Tentang Asumsi-asumsi Dasar Teori Hukum Murni-Hans Kelsen*
}

\author{
Kelik Wardiono \\ Magister Ilmu Hukum Universitas Muhammadiyah Surakarta \\ E-mail: kelik_wardiono@ums.ac.id; liekums@gmail.com \\ dan \\ Khudzaifah Dimyati \\ Program Doktor Ilmu Hukum Universitas Muhammadiyah Surakarta \\ E-mail: khudzaifah_dimyati@ums.ac.id, kdimyati@yahoo.com
}

\begin{abstract}
Based on the philosophical approach, it is known basic assumptions of rational paradigm as seen in Hans Kelsen's pure theory of law that consists of: human assumptions based on the quasitranscendental along with its characters and aurea aetas; ontological assumptions based on empirical reality and equating sein reality with sollen, and normativity created as logico transcendental conditions; epistemological assumption that underlying the science of law as cognitive science, creating the rule of law as a whole object, and reconstructing legal norm as the relation between non-causal and non-metaphysical facts; axiological assumption that reconstructs norm as the object of legal science and equating the basic norms with natural laws.
\end{abstract}

Key words: basic assumptions, rational paradigm, the theory pure of law, jurisprudance.

\begin{abstract}
Abstrak
Dengan mendasarkan pada pendekatan filosofis, diketahui asumsi-asumsi dasar dari paradigma rasional sebagaimana terlihat dalam teori hukum murni Hans Kelsen terdiri dari: asumsi manusia, yang berkarakter quasi-transendental dan aurea aetas; asumsi ontologis yang mendasarkan pada realitas empiris dan menyamakan realitas sollen dengan sein, dan normativitas dijadikan sebagai kondisi logiko transendental; asumsi epistemologis, yang menempatkan ilmu hukum sebagai ilmu kognitif, menjadikan norma hukum sebagai satu kesatuan objek, dan norma hukum yang direkonstruksi terbentuk dari relasi antara fakta-fakta yang bersifat non-kausal dan non-metafisikal; asumsi aksiologis menempatkan norma yang direkonstruksi sebagai objek ilmu hukum dan menyamakan norma dasar dengan hukum alam.
\end{abstract}

Kata Kunci: asumsi, paradigma rasional, teori hukum murni, ilmu hukum.

\section{Pendahuluan}

Sejarah manusia untuk menemukan pengetahuan yang benar, bergulir melalui proses dialektik, sesuai dengan perubahan ritme kesadaran paradigmatik dari para ilmuan yang menjadi pendukungnya, maupun melalui the paradigm shift.

- Artikel ini merupakan hasil peneltian Program Peneltian Desentrasilasi, Skim Peneltian Disertasi Doktor, dengan Nomor Kontrak: 194.59/A.3-III/LPPM/V/2014, Tahun Anggaran 2013/2014
Paradigma, meskipun menempati posisi strategis bagi para ilmuan sehingga akan selalu melindunginya dari berbagi kritik serta falsifikasi, akan tetapi dalam satu cabang ilmu, tidaklah hanya terdapat satu paradigma. Ilmu hukum sebagaimana dikemukakan oleh Soetandyo Wognjoseobroto, paling tidak terdapat tiga paradigma besar yang mempengaruhi perkembangan ilmu hukum, yaitu: paradigma moral (the ideal law), paradig- 
ma rasional (the rational law) dan paradigma saintisme (the scientific law/empirical laws). ${ }^{1}$

Arti penting paradigma tersebut, karena di dalamnya terdapat unsur-unsur yang menjadi mode of thought, mode of inquiry, dan mode of knowing, bagi para ilmuan dalam mempelajari dan mengembangkan ilmunya, ${ }^{2}$ sehingga melalui paradigma inilah akan terlihat bagaimana konsepsi dan sistematika berpikir dari para ilmuan ketika melihat sebuah objek atau kerangka tertentu dalam memahami sesuatu. Bila mengikuti pendapat Heddy Shri Ahimsa Putra, tentang unsur-unsur pokok paradigma, yaitu terdiri dari: asumsi-asumsi dasar, nilai-nilai, model, masalahmasalah yang diteliti, konsep-konsep, metode penelitian, metode analisis, hasil analisis atau teori dan representasi (etnografi), ${ }^{3}$ maka tiga unsur yang pertama, yaitu asumsi-asumsi dasar, nilai-nilai dan model, menurut Heddy Shri Ahimsa Putra merupakan basis epsitemologi dari sebuah paradigma dan merupakan bagian yang relatif lebih penting daripada unsur-unsur yang lain, karena ketiga unsur tersebut pada dasarnya merupakan isi epistemologi dari sebuah paradigma, sedangkan keenam unsur yang lain, merupakan implikasi dari basis epistemologisnya. ${ }^{4}$

Hans Kelsen, melalui apa yang disebutnya sebagai The Scientific-Critical Philosophy (filsafat ilmiah kritis), telah berupaya menyusun argumen-argumen basis epistemologi bagi teori yang dibangun dan dikembangkannya yaitu teori hukum murni (pure theory of law). Melalui argu-

Soetandyo Wignjosoebroto, "Memperbincangkan 'Hukum' Dari Perspektif Filsafat: Paradigma Hukum dan Pergeserannya dalam Sejarah", Jurnal Digest Epistema, Vol. 1, Tahun 2011, Jakarta: Epistema Institut, hlm. 9-11.

2 Sidik Ibrahim, "Paradigma Islam Dan Transformasi Sosial (Studi Pemikiran Kuntowijoyo)", Hunafa: Jurnal Studia Islamika, Vol. 2 No. 3. Palu : Institut Agama Islam Negeri (IAIN) Palu Sulawesi Tengah, hlm. 247; Bambang Wahyu, "Filsafat Ekonomi Islam: Rasionalitas dan Religiusitas Ekonomi”, Jurnal Ekonomi Islam Al-Infaq, Vol. 1 No. 1, September 2010, Bogor : Program Studi Ekonomi Islam Fakultas Agama Islam Universitas Ibn Khaldun Bogor, hlm. 48.

3 Heddy Shri Ahimsa-Putra, "FENOMENOLOGI AGAMA: Pendekatan Fenomenologi untuk Memahami Agama", Walisongo Walisongo: Jurnal penelitian sosial keagamaan, Vol. 20, No. 2, November 2012, Semarang: Lembaga Penelitian (LEMLIT) IAIN Walisongo Semarang, hlm. 273.

4 Heddy Shri Ahimsa Putra, 2011, Paradigma, Epistemologi dan Etnografi dalam Antropologi, Makalah disampaikan dalam ceramah "Perkembangan Teori dan Metode Antropologi", diselenggarakan oleh Departemen Antro- men-argumennya filosofis di dalam teorinya inilah, Hans Kelsen menawarkan sebuah basis epistemologi "baru" di dalam ilmu hukum, yang menurutnya merupakan sebuah jalan tengah di antara dua maistream ilmu (filsafat) hukum, yaitu teori hukum alam (yang merupakan bagian dari paradigma moral) dan teori hukum empiris-positivistik (yang merupakan bagian dari paradigma saintisme). ${ }^{5}$

Teori hukum murni merupakan jawaban yang diberikan Kelsen untuk menyelesaikan persoalan antinomi yurisprudensi. ${ }^{6}$ Kelsen, oleh karenanya melakukan penolakan terhadap tesis moralitas dan tesis keterpisahan, dan sebagai gantinya mendasarkan pada (gabungan) antara tesis normativitas (tanpa tesis moralitas) dan tesis keterpisahan (tanpa tesis reduktif). Kelsen, melalui tesis-tesis yang menjadi dasar dari teorinya ini, berupaya melakukan "purify" (pemurnian) dalam 3 hal. Pertama, pemurnian terhadap objek teori hukum; kedua, pemurnian tujuan dan ruang lingkup teori hukum dan ketiga, pemurnian terhadap metodologi teori hukum. ${ }^{7}$ Kelsen, dengan demikian mengklaim telah berhasil memecahkan antinomi yurisprudensi yang bersumber dari pemahaman tradisional tentang jukstaposisi teori hukum alam (natural law theory), dan teori hukum empiris-positivistik (empirico-positivist theory of (aw). ${ }^{8}$ Teori hukum murni ini pun menurut Kelsen merupakan bagian dari upaya untuk menyelesaikan persoalan dualisme metafisik-religius, yang selama ini menimbulkan persoalan

pologi, Fakultas Ilmu Sosial dan Ilmu Politik, Universitas Airlangga, di Surabaya, 6-7 Mei 2011, hlm. 19.

5 Kendra Frew, "Hans Kelsen's Theory and The Key to His Normativist Dimension", The Western Australian Jurist Journal, Vol. 4, Tahun 2013, Murdoch University: Western Australian Legal Theory Association (WALTA), hlm. 287.

6 Stanley L. Paulson, “The Neo-Kantian Dimension of Kelsen's Pure Theory of Law, Oxford Journal of Legal Studies", Vol. 12, No. 3, Autumn 2005, hlm. 319.

7 Hans Kelsen, 2007, Pure Theory of Law: Legality and Legitimacy, transltaed by Lars Vinx, New York: Oxford University Press, , hlm. 7 dan 11; bandingkan dengan Milijan Popovic, 2002, "Methodological Models of The General Theory of Law", facta Universitates, series: Law and Politics Jurnal, Vol. 1 No. 6, Tahun 2002, hlm. 659-682.

8 Christoph Kletzer, 2013, Absolute Positivism, Netherlands Journal of Legal Philosophy, Aflevering 2-2013, tersedia di http://www.bjutijdschriften.nl/tijdschrift/ rechtsfilosofieentheorie/2013/2/NJLP_2213-0713_2013_ 042_002_002. 
tersendiri dalam ilmu hukum, sehingga perlu dipikirkan kemungkinan adanya tipe ketiga, sebagai jalan tengah antara dualisme pesimistik dan optimistik. ${ }^{9}$

Berdasarkan deskripsi di atas, maka penelitian ini berusaha untuk menemukan basis epistemologi dari paradigma rasional, terutama yang terlihat dalam struktur epistemologis teori hukum murni dari Hans Kelsen. Dalam hal ini tidak semua unsur basis epistemologi akan dibahas, akan tetapi hanya akan memfokuskan pada satu unsur saja, yaitu asumsi-asumsi dasar dari basis epistemologi teori hukum murni.

\section{Permasalahan}

Berdasarkan deskripsi problematika sebagaimana terurai di atas, maka masalah yang akan dikaji pada artikel ini adalah mengenai asumsiasumsi dasar dari paradigma rasional, yang didukung oleh mazhab filsafat hukum positivisik, sebagaimana yang terlihat dalam teori hukum murni dari Hans Kelsen.

\section{Metode Penelitian}

Penelitian ini mendasakan pada pendekatan filosofis, karena dimaksudkan untuk mengeksplorasi bangunan basis epistemologi dari paradigma rasional, yang didukung oleh mazhab filsafat hukum positivisik, sebagaimana yang terlihat dalam teori hukum murni dari Hans Kelsen. Sumber utama yang berupa informasi yang berasal dari tulisan dan pemikiran Hans Kelsen tentang teori hukum murni, dikumpulkan melalui studi kepustakaan. Data yang telah diolah, dianalisis dengan analisis deskriptif, interpretasi dan hermeneutik dan heurestik.

\section{Pembahasan}

Pembahasan tentang asumsi-asumsi dasar dari teori hukum murni Hans Kelsen, sebagai ilmu hukum yang terbentuk oleh paradigma rasional yang didukung madzhab filsafat hukum posi-

9 Untuk persoalan dualisme metafisik transendental, lihat lebih lanjut Hans Kelsen, 2011, General Theory of Law and State...., Appendix: The Epistemological (Metaphysical) and Psychological Foundation, hlm. 419-423.

10 Keseluruhan uraian tentang aspek ontologi (kecuali untuk bagan-bagian yang secara khusus disebutkan dari sumber lain), diambil dari: Hans Kelsen, 2008, Intro- tivistik, akan diawali dengan dideskripsi tentang subtansi dari teori hukum murni dilihat dari perspektif epistemologi, yaitu dari aspek-aspek ontologi, epistemologi dan aksiologinya.

\section{Teori Hukum Murni: Sebuah Deskripsi Aspek Ontologi $^{10}$}

Kelsen, secara ontologis mengatakan bahwa, yang menjadi objek dari kognisi ilmu hukum adalah norma hukum, ${ }^{11}$ yaitu norma-norma yang memiliki karakter norma hukum dan yang menjadikan perilaku/tindakan tertentu bersifat legal atau illegal. Norma-norma hukum yang menjadi objek kognisi dari ilmu hukum, memiliki karakter sebagai berikut.

Pertama, norma hukum sebagai makna tindakan berkehendak. Dalam perspektif teori hukum murni, ilmu hukum diarahkan pada upaya untuk memahami norma hukum sebagai makna tindakan (perilaku/perbuatan) berkehendak. Dengan demikian meskipun objek dari ilmu hukum, berupa norma hukum dan perilaku manusia yang terkandung dalam norma hukum, akan tetapi yang menjadi obyeknya semata-mata hanyalah norma, bukan perilaku manusia/tindakan berkehendak itu sendiri. Teori hukum murni, khusus diarahkan kepada norma hukum, ia tidak diarahkan kepada fakta; ia tidak diarahkan pada tindakan berkehendak yang bermaknakan norma hukum, tetapi kepada norma hukum sebagai makna dari tindakan berkehendak. Makna dari tindakan berkehendak dan hubungan timbal baliknya inilah yang merupakan pokok bahasan teori hukum murni.

Kognisi ilmu hukum, meskipun pada awalnya selalu diarahkan pada upaya untuk menetapkan fakta/tindakan yang berdimensi alamiahempiris, akan tetapi tindakan yang dilakukan ini bukan/belum termasuk dalam kognisi hukum. Bagian ini merupakan tahapan pra kognisi yang ditujukan untuk mengidentifikasi, apakah suatu fakta material (tindakan) tertentu, dapat diper-

duction to the Problem of Legal Theory, a translation of the Reine Rechtslehre or Pure Theory of Law by Bonnie Litschewski Paulson and Stanley L. Paulson, re-printed, Oxford University Press : Clarendon Press, hlm.7-35; 5571.

11 Hans Kelsen, 2007, Pure Theory of Law ..., hlm. 70. 
kirakan merupakan salah satu dari katagori peristiwa/tindakan yang (telah ditetapkan) dalam norma atau bukan. Kognisinya menjadi hukum ketika ia menafsirkan fakta material yang telah diperkirakan pada tahap pra-kognisi, sebagai sebuah katagori yang ditetapkan dalam norma. Penafsiran ini hanya mungkin dilakukan jika muatan fakta material tersebut diketahui dengan cara yang sangat khusus, yaitu sebagai muatan norma. Proses pemberian makna normatif terhadap fakta metarial yang teramati ini, merupakan momen yang penting, karena dengan adanya proses ini sebuah norma hukum menjadi mengada/eksis/ berlaku (atau Hans Kelsen menyebutnya sebagai norma yang sah/valid). Sebuah perilaku/peristiwa dinyatakan sah atau tidak sah, bukan karena realitanya (sifat alamiahnya). Akan tetapi karena maknanya, logika objektif yang melekat pada tindakan tersebut, yaitu muatan aktual dalam perilaku/peristiwa tersebut sesuai dengan muatan norma. Norma-norma yang memberikan karakter sah (atau tidak sah) pada fakta materiil inilah yang men-jadi tujuan kognisi hukum.

Kedua, norma hukum, sebagai norma moral relatif yang berkarakter normatif. Hukum dan moral dalam aspek tertentu, meskipun memiliki kesamaan, akan tetapi menurut Kelsen dua norma tersebut berbeda. Perbedaannya bukanlah pada isinya, melainkan pada bentuknya. Hal ini disebabkan, karena moral sebagai bagian dari tatanan dan nilai yang absolut, hanya bisa diterima berdasarkan keyakinan religius dalam otoritas absolut dan transenden ketuhanan, sehingga harus ditolak berdasarkan sudut pandang ilmiah, karena tatanan moral absolut, akan meniadakan kemungkinan pemberlakuan tatanan moral lainnya, yang ada secara empiris. Bila ini yang terjadi, maka norma hukum sebagai salah satu tatanan sosial, akan kehilangan eksistensinya.

Setiap sistem yang bersifat "seharusnya" pada dasarnya dapat diklasifiksaikan sebagai sebuah sistem moral (yang bersifat "seharusnya"/ perintah), yang memiliki karakter normatif. Dengan demikian, apa yang diperintahkan oleh ta- tanan pemaksa tersebut dapat dianggap baik dan adil, dan apa yang dilarang adalah kejahatan dan ketidakadilan, oleh karena itulah, apa yang baik secara moral bukanlah apa yang termasuk dalam nilai moral a-priori, yang bersifat absolut, akan tetapi adalah yang sesuai dengan norma sosial yang menetapkan perilaku manusia tertentu, sehingga apa yang dinilai jahat secara moral, adalah apa yang bertentangan dengan norma tersebut. Nilai moral relatif, diwujudkan oleh norma sosial yang menyatakan bahwa manusia harus berperilaku dengan cara tertentu.

Dengan demikian ungkapan yang menyatakan bahwa "hukum pada dasarnya adalah moral", tidak berarti bahwa hukum memiliki isi tertentu, tetapi bahwa ia sendiri adalah "moral" yakni sebuah norma sosial yang menyatakan bahwa manusia harus berperilaku dengan cara tertentu. Setiap hukum, karenanya dalam pengertian relatif ini, adalah moral (nilai moral relatif).

\section{Aspek Epistemologi ${ }^{12}$}

Ilmuan hukum yang mengghasilkan aturan hukum, memiliki posisi yang berbeda dengan otoritas hukum, yang menciptakan norma yang dipatuhi oleh subjek hukum. Hans Kelsen membedakan antara aturan hukum/rule of law (Recht Satz) sebagai pernyataan hipotetis yang dibuat oleh ilmu hukum dengan norma hukum/legal norm (Recht-Norm) sebagai norma yang dikeluarkan oleh otoritas pembuat norma. ${ }^{13}$ Aturan hukum (dalam arti deskriptif), merupakan penilaian hipotetis yang menyatakan bahwa menurut tatanan hukum tertentu, berdasarkan persyaratan yang ditetapkan oleh tatanan tersebut, konsekuensi atau sanksi tertentu yang ditetapkan oleh tatanan itu harus diterapkan. Ilmu hukum hanya dapat menjelaskan hukum, ia tidak dapat memutuskan perilaku tertentu, seperti yang dapat dilakukan oleh hukum yang diciptakan oleh otoritas hukum. Ilmu hukum berfungsi untuk menganalisis norma-norma sebagai obyek kognisi, untuk mengetahui dan menjelaskan norma hukum, ${ }^{14}$ serta

\footnotetext{
13 Lihat Hans Kelsen, 2007, Pure Theory of Law ..., Op. Cit, $\mathrm{hlm} 72$.

14 lbid, hlm. 68 and 69.
}

12 Keseluruhan uraian tentang aspek aksiologi (kecuali untuk bagan-bagian yang secara khusus disebutkan dari sumber lain), diambil dari: Hans Kelsen, 2007, Pure Theory of Law.... Op. Cit, hlm. 70. 
hubungan, yang ditetapkan oleh norma, antara fakta-fakta yang ditetapkan oleh norma.

Berdasarkan deskripsi diatas, maka dapatlah diketahui bahwa fungsi dari ilmu hukum, adalah sebagai berikut. Pertama, mengetahui hukum yang berlaku terhadap suatu perilaku/ peristiwa kongkrit tertentu. ${ }^{15}$ Menurut Kelsen tujuan dari ilmu hukum adalah menunjukan dan menetapkan norma hukum yang berlaku terhadap suatu perilaku/peristiwa kongkrit tertentu. Dalam hal ini ilmu hukum berfungsi merekonstruksi berbagai norma hukum umum dan individual, yang diciptakan oleh otoritas hukum, menjadi sebuah sistem yang manunggal, sebuah "tatanan" hukum (menciptakan obyeknya), sehingga hukum yang ada tersebut dapat dipahami sebagai keseluruhan. Kelsen, untuk dapat melakukan hal tersebut, telah menyediakan sebuah teori, yang merujuk pada teori struktur hierarkis (Stufenbaulehre) Adolf Julius Merkl, ${ }^{16}$ yang dapat digunakan untuk menjelaskan kesatuan sejumlah norma hukum yang sah, yang dapat diberlakukan terhadap perilaku/peristiwa konkrit tertentu.

Menurut Hans Kelsen, sebuah norma menjadi bagian sistem hukum tertentu, hanya berasal dari fakta bahwa keabsahan norma yang bersangkutan, bisa diruntut kembali sampai ke norma dasar yang menyusun sistem tersebut. Dalam sebuah tatanan hukum positif, ada beragam norma khusus, yaitu, norma-norma umum, yang berupa: kebiasaan atau legislasi dan norma-norma khusus, berupa: tindakan adjudikatif, dan transaksi hukum privat. Sebuah tindakan koersif menjadi sebuah tindakan hukum, karena tindakan tersebut termasuk dalam sistem hukum tertentu (masuk dalam sebuah norma umum/individual tertentu).

Sebuah norma umum atau norma individual menjadi sah, karena norma-norma tersebut dikeluakan atau ditetapkan sesuai dengan prosedur yang ditetapkan dalam norma yang ada, yang le-

15 lbid, hlm. 72, 193-221.

16 Tentang pengadopsian teori struktur hierarkis (Stufenbaulehre) Adolf Julius Merkl, lihat lebih lanjut, Stanley L. Paulson, "How Merkl's Stufenbaulehre Informs Kelsen's Concept, Revus", Journal for Constitutional Theory and Philosophy of Law, Vol. 21, Tahun 2013, tersedia di web: http://revus.revues.org/2727, Klub Revus: Center za raziskovanje evropske ustavnosti in de-mokracije, $\mathrm{hlm}$. 29-45. bih tinggi. Hal ini akan berlanjut terus hingga sampai pada konstitusi negara yang bersangkutan, yang bila ditelusuri lebih lanjut akan merujuk pada konstirusi sebelumnya, dan kemudian akan berakhir pada konstitusi yang pertama, yang menurut sejarah ditentukan oleh "para" pengambil alih kekuasaan. Apa yang dianggap sah sebagai norma adalah apa yang diungkapkan oleh pada pembuat konstitusi pertama sebagai kehendak mereka. Inilah perkiraan dasar semua kognisi tentang sistem hukum yang didasarkan pada konstitusi.

Teori hukum murni menggunakan norma dasar sebagai dasar hipotesis, dengan mendasarkan pada perkiraan, bila norma dasar sah, maka sistem hukum yang berdasarkan padanya akan sah. Norma dasar memberi pengertian "keharusan" pada tindakan pembuat undang-undang pertama suatu pengertian khusus yang menghubungkan kondisi hukum dengan konsekuensi hukum dalam norma hukum yang direkonstruksi.

Kedua, menjelaskan hukum yang diberlakukan terhadap perilaku/peristiwa faktual-konkrit. ${ }^{17}$ Tatanan norma perilaku manusia, dapat dijelaskan dengan sebuah prinsip, yang oleh Hans Kelsen disebut prinsip imputasi (pengatributan). ${ }^{18}$ Imputasi mendasarkan prinsip: pada kondisi tertentu, konsekuensi tertentu semestinya terjadi; dengan perkataan lain: jika hubungan antar fakta-fakta yang diciptakan oleh norma yang ditetapkan dalam norma hukum sebagai kondisi dan konsekuensi diungkapkan dengan kata "mestinya", dengan pengertian yang berbeda pada umumnya. Kata "mestinya" yang bersifat hukum: yakni konjungsi yang dalam aturan hukum menghubungkan kondisi dan konsekuensi, mencakup tiga makna: perintah, pemberian wewenang, dan pemberian izin positif atas suatu konsekuensi.

Kata "mestinya" dalam aturan hukum, mengacu pada ketiga fungsi normatif. Kata "semes-

17 Ibid, hlm. 75-192.

18 Hans Kelsen, 2008, Introduction to the Problem of Legal Theory.... Op. Cit, hlm. 7-10; Boris Milosavljević, Boris Milosavljević, "An Early Critique Of Kelsen 'S Pure Theory Of Law: Slobodan Jovanović On The Basic Norm And Primacy Of Inetrnational Law", Belgrade Law Review, Year LXI No. 3, 2013, Serbia: Faculty of Law - University of Belgrade, hlm. 156 
tinya" ini, hanya mengungkapkan makna khusus, dimana kedua fakta itu, dihubungkan oleh sebuah norma hukum, yang berarti di dalam norma hukum. Ilmu hukum hanya dapat mengungkapkan hubungan yang diciptakan oleh norma tersebut, khususnya hubungan antara pelanggaran dan sanksi, dengan konjungsi "semestinya". Ilmu hukum, dalam konteks yang demikian, maka dapat merumuskan aturan hukum dengan mengatakan bahwa "menurut tatanan hukum positif tertentu, dan berdasarkan kondisi tertentu, konsekuensi tertentu harus diterap-kan".

Hubungan antara kondisi dan konsekuensi yang diungkapkan dengan kata "harusnya" dalam ilmu hukum disebut "imputasi”. Konsep imputasi tersirat dalam konsep "pertanggungjawaban". Pertanggungjawban yang dimiliki oleh seorang individu atas perbuatannya bermakna bahwa: dia bisa dihukum atas perbuatan ini; dan bila ia dinyatakan tidak bertanggungjawab, ini berarti ia tidak akan dihukum atas perbuatan yang sama. Pengalamatan yang ditunjukan dalam konsep pertanggungjawaban, bukan merupakan kaitan antara perbuatan tertentu dengan seorang individu yang berbuat, akan tetapi antara perbuatan dengan sanksi. Dengan demikian imputasi atau pengalamat, hanya terdapat dalam hubungan antara perbuatan tertentu, yakni pelanggaran, dengan sanksi. Sanksi dialamatkan kepada pelanggaran, namun sanksi tidak "dipengaruhi oleh" (atau tidak "disebakan oleh") pelanggaran. Ilmu hukum tidaklah ditujukan pada penjelasan sebab akibat dari fenomena hukum yang berupa pelanggaran dan sanksi. Imputasi sebagai terjemahan dari zurechnung (responsibility), pernyataan bahwa seseorang individu adalah zurechnung (responsible), bermakna saksi dapat dibebankan kepadanya, jika ia melakukan suatu pelanggaran. ${ }^{19}$

Prinsip imputasi ini, menurut Hans Kelsen mendasakan pada penafsiran masyarakat primitif atas alam. Jika terjadi suatu peristiwa yang dalam kesadaran masyarakat primitif memerlukan penjelasan, dan ini hanya merupakan kejadian yang secara langsung mempengaruhi kepen-

19 William Ebenstein, "What Is Justice? Justice, Law by Hans Kelsen”, Journals American Political Science Re-view. tingan mereka, mereka tidak akan mengajukan pertanyaan: "apa yang menyebabkan terjadinya hal ini", tetapi "siapa yang bertanggungjawab atas hal ini". Penafsiran mereka bukanlah penafsiran sebab-akibat, melainkan penafsiran normatif terhadap alam; dan karena norma retribusi yang mendasari munculnya penafsiran ini merupakan prinsip sosial yang secara khusus mengatur perilaku timbal balik sesama manusia, maka jenis penfasiran terhadap alam bisa dicirikan sebagai penafsiran sosionormatif.

Prinsip imputasi ini bisa dirujuk akarnya dalam pemahaman animisme manusia primitif, yang berpandangan semua benda di alam semesta memiliki ruh, merupakan persona, yang akan memberikan responnya satu sama lain berdasarkan prinsip retribusi atau penggantian kerugian (mencakup hukuman dan imbalan). Prinsip tersebut secara umum terumus: jika kita berbuat benar, maka kita kan mendapat imbalan, yakni kebaikan akan akan kita dapatkan; jika kita berbuat salah, kita akan dihukum, yakni bahwa keburukan atau kejahatan akan ditimpakan kepada kita. Dalam prinsip ini kondisi dan konsekuensi tidak dikaitkan satu sama lain berdasarkan prinsip kausalitas, tetapi berdasarkan prinsip imputasi.

Pertanyaan dalam prinsip imputasi bukanlah siapa yang telah melakukan amal kebaikan? atau siapakan yang telah berbuat dosa atau kejahatan? Ini merupakan pertanyaan tentang fakta; pertanyaan moral atau hukum mengenai imputasi adalah: siapakah yang bertanggungjawab atas perbuatan itu? Pertanyaan ini berarti: siapa yang sebaiknya diberi penghargaan atau siapa yang harus menebus kesalahan atau dihukum?. Hal yang diimputasikan sebagai konsekuensi khusus pada kondisi khusus adalah penghargaan atas kebajikan, penebusan dosa atas perbuatan dosa, dan penghukuman atas tindakan kejahatan.

\section{Aspek Aksiologi}

Tujuan utama dari teori hukum murni adalah membebaskan/memurnikan ilmu hukum dari anasir-anasir asing yang selama ini secara langsung atau pun tidak terakomodasi di dalam ilmu

Vol. 52, Issue 02, 2013, Published online by Cam-bridge University Press 02 Sep 2013, hlm. 536. 
hukum "tradisional". ${ }^{20}$ Kelsen, oleh karenanya dalam membangun teori, berupaya menghindari dan meniadakan segala sesuatu yang bukan termasuk obyek kognisi ilmu hukum, terutama "unsur-unsur asing" yang teridentifikasi sebagai bukan hukum, ${ }^{21}$ dan mencanangkan konsep norma dasar, yaitu pengandaian satu kondisi logikotransendental bagi kognisi dalam ilmu hukum, sebagai pilar utama (elemen sentral) dari teori hukum yang "dimurnikan", yaitu teori yang dimurnikan dari metafisika dan sinkretisme metodologis yang berlaku.

Berdasarkan hal tersebut, kemudian Kelsen menyatakan bahwa, hukum adalah norma, dan inilah yang menjadi satu-satunya obyek kognisi hukum". ${ }^{22}$ Norma sebagai objek kognisi hukum yang berbeda dengan norma yang menjadi objek ilmu hukum menurut mazhab hukum kodrat, maupun mazhab hukum empiris-positivistik. Norma hukum sebagai norma adalah realitas ideal, namun demikian tidak berarti hukum akan menjadi bagian dari moralitas dan kemudian memberi nilai mutlak berdasarkan standar moralitas kepada hukum. Hukum sebagai kategori moral kemudian diidentikan dengan keadilan. Keadilan bagi Kelsen adalah kesesuaian dengan hukum positif. Suatu norma umum, jika diterapkan pada satu kasus, akan tetapi tidak diterapkan pada kasus sejenis yang muncul, maka dikatakan "tidak adil", ketidakadilan yang terlepas dari berbagai pertimbangan moral dan nilai norma umum tersebut. Adil adalah mengungkap nilai kecocokan relatif dengan sebuah norma; adil adalah kata lain dari sah.

Berdasarkan deskripsi di atas, dapatlah diketahui bahwa, melalui pemurnian yang dilakukan, maka norma-norma sebagai objek kognisi hukum tidak diarahkan untuk merealisasikan nilai-nilai moral absolut (keadilan) ataupun "seke- dar" mengakui dan mewujudkan nilai-nilai yang terbentuk dari perilaku-perilaku yang terpolakan sebagai perilaku hukum (kemanfaatan), akan tetapi berupaya mewujudkan nilai-nilai yang ditetapkan di dalam norma hukum itu sendiri (kepastian hukum).

\section{Teori Hukum Murni: Asumsi-asumsi Dasar ${ }^{23}$ Asumsi tentang Manusia}

Hans Kelsen, di dalam filsafanya mambagi manusia ke dalam tiga tipe, yaitu: pessimistic dualism, optimistic dualism, dan the compromise type of metaphysical dualism. Tipe-tipe manusia ini muncul, karena adanya perubahan pemahaman dan kedasaran manusia tentang dunia, yaitu asumsi tentang adanya relasi antara filsafat moral dan kosmik, dalam merespon konsep dualisme metafisik religius. Manusia berkarakter ilmiah-kritis adalah sinonim dari manusia bertipe the compromise type of metaphysical dualism. ${ }^{24}$ Manusia yang akan mendukung teori hukum murni, menurut Hans Kelsen, adalah manusia berkarakter ilmiah-kritis, yaitu manusia-manusia yang telah dapat mengatasi pandangan dualisme metafisika religius, dengan karakter sebagai berikut:

Pertama, manusia berkarakter ilmiah-kritis adalah manusia quasi-transendental. Manusia manusia berkarakter ilmiah kritis, terutama disebabkan karena disatu sisi, relatif berkurangnya kepercayaan manusia, melalui pengalaman, dengan sarana jiwa manusia, pada kemampuannya untuk mencapai kebenaran illahiah, serta ketidakpercayaan pada kekosongan atau kehampaan (nothingness) dan kesia-siaan semua benda bu$\mathrm{mi}$, sedang di sisi lain manusia tidak sepenuhnya meragukan kemampuannya untuk memahami dunia. ${ }^{25}$

Kelsen, 2011, General Theory of Law and State, Appendix: The Epistemological (Metaphysical) and Psychological Foundation, Translated by Anders Wedberg, United States: Imprint Lawbook Exchange, hlm. 419-444.

24 Lihat Hans Kelsen, 2011, General Theory of Law and State, .... Loc. Cit.

25 Mónica García-Salmones Rovir, 2013, The Politics Of Interest In International Law, New York University School of Law: The Jean Monnet Center for international and Regional Economic Law and Justice, tersedia di web: www.JeanMonnetProgram.org. hlm. 24 
Manusia tidak membutakan matanya terhadap kenyataan bahwa dunia ini bukanlah yang terbaik. la menghadapi kenyataan dengan teguh, berdasarkan penalaran yang tidak lebih lemah dari rasa sentimentilnya, serta cukup kuat untuk tidak tertipu oleh keinginan serta kepentingannya. Manusia menerima kehidupan dunia seperti adanya, dan berusaha menghadapinya dengan berani, meski penuh kesedihan. Ini berarti orang harus menerima perintah, terutama yang diberikan oleh hukum positif dan otoritas politik, dan juga menerima norma-norma yang sahih yang diberikan oleh penegak hukum yang kompeten, walaupun perintah-perintah itu nampak tidak adil. Dunia empirik, dan terutama dunia sosial secara relatif dipahami sebagai dunia yang baik karena dunia empirik dan sosial tidak sepenuhnya buruk. Baik dan buruk, keadilan dan ketidakadilan merupakan istilah yang relatif, perubahan yang signifikan terjadi dalam sistem ini.

Kedua, manusia berkarakter ilmiah-kritis, adalah manusia aurea aetas. Manusia berkarakter ilmiah kritis, pada umumnya sangat mendambakan terwujudnya kembali kebahagiaan duniawi yang telah lama hilang, kebahagiaan dalam kehidupan di masa silam, ketika dewa-dewa berjalan ditengah umat manusia atau berbicara langsung dengan manusia, yaitu dunia aurea aetas. Dunia yang merupakan simbol rekonsiliasi duniawi dan surgawi.

Citra aurea aetas ini tidak dipertentangkan, dengan citra masyarakat masa depan yang sempurna. Dengan demikian manusia berkarakter ilmiah kritis berupaya untuk membangun jembatan yang menghubungkan masa lalu yang penuh kebahagiaan dengan masa kini yang kurang membahagiakan dengan mengungkapkan bahwa semua elemen esensial dari tatanan yang sekarang ada, bisa ditemukan, setidak-tidaknya dalam bentuk yang paling dasar, di surga awal kehidupan, karena di masa keemasan itulah (yaitu kehidupan seputar kehidupan awal kepolosan manusia surgawi) tatanan positif negara menjadi mungkin.

Manusia berkarakter ilmiah kritis percaya kondisi yang ada sekarang ini, dapat diperbaiki. Mereka memiliki kepercayaan pada proses evolusi ke tingkat yang lebih tinggi dan tidak m-no- lak adanya reformasi yang penting, akan tetapi menolak keberadaan surga akhirat yang toto ceolo berbeda dari neraka saat ini. Relativismenya, yang menerima ide adanya perkembangan yang bertahap, membuat hal tersebut menjadi tidak mungkin. la memilih mencari realisasi dari ide sosial di waktu lalu. la terlalu kritis dan berhatihati untuk membenani dirinya dengan janji-janji seputar kehidupan masa depan yang gemilang, karena itu pandangan mengenai keberadaan surga pada waktu permulaan waktu menjadi ciri khas pengikut filsafat ini. Dengan demikian cerita tentang masa silam yang indah itu memegang peranan penting dalam filsafat ini.

\section{Asumsi Ontologis Teori Hukum Murni}

Realitas adalah Realitas Empiris yang Didukung oleh Realitas Transendental

Dunia adalah seperti apa yang tampak di mata kita, karena bagi kita tidak ada, dan tidak akan ada dunia lain. Dunia kita adalah adalah dunia satu-satunya. Oleh karena itu, dunia menjadi satu-satunya dunia yang nyata. Demikian pandangan dan pemahaman pokok Kelsen tentang realitas.

Orang tidak lagi berusaha menyelesaikan konflik tentang dua dunia dengan menghilangkan salah satu dari kedua dunia tersebut, tetapi orang berusaha menyelesaikan konflik tersebut dengan menegaskan bahwa kedua dunia tersebut saling berkaitan. Benda-benda bumi, maka dari itu pada dasarnya juga dianggap sebagai emanasi dari kekuatan supernatural yang sempurna.

Dunia di luar dunia ini, tidak lagi berfungsi meniadakan "yang disini dan sekarang", yakni dunia pengalaman manusia, tetapi lebih berfungsi menjelaskan dunia pengalaman itu sendiri. Dengan demikian ide-ide transenden tersebut menyesuaikan dengan pengalaman. Pada saat manusia merasa yakin dengan kebenaran sains, kemudian memperluas serta memperdalamnya karena ia memperoleh pengetahuan yang baik seputar "objek tiruan", maka citra asli itu sendiri (ide) harus mengubah kandungannya sesuai dengan pengalaman atau, karena keberagaman semacam ini bertentangan dengan esensi ide-ide tersebut, maka ide-ide ini harus mengosongkan 
konsep yang dikandungnya dan secara sadar serta terbuka, mengubahnya menjadi pola-pola yang formal.

Pandangan ini tidak hanya memandang dunia sebagai sesuatu yang berharga, bahkan cenderung melihat sebagai sebagai yang terbaik, atau setidak-tidaknya merupakan yang terbaik dari semua kemungkinan yang ada, karena itu manusia, yang beranggapan bahwa dirinya merupakan citra Tuhan, pertama-tama harus membentuk Tuhan sesuai dengan imajinya sendiri dan kemudian, karena merasa takut akan keserupaan Tuhan dengan manusia, memformulasikan Tuhan dalam konsep kosong. Orang berusaha menyelesaikan konflik kedua dunia itu tidak dengan cara menghilangkan salah satu daripadanya, tetapi dengan menegaskan bahwa kedua dunia itu saling bekaitan.

Realitas Terbagi Dua: Realitas Seharusnya (Sollen; Ought) dan Senyatanya (Sein; Is); dan Merupakan Realitas yang Sedarajat.

Menurut Han kelsen dunia terbagi dalam dua domain besar, yaitu dunia sollen; ought (seharusnya; alam ideal; normatif) dan dunia sein; is (senyatanya; alam fisik; ada). Sollen dan Sein merupakan kategori-kategori puncak (ultimate) yang bersifat fundamental bagi penjelasan terhadap segala sesuatu yang lainnya, sehingga dua dunia ini masing-masing sepenuhnya mandiri dan dipisahkan oleh jurang yang tidak bisa terjembatani secara epistemologi. ${ }^{26}$

Hans Kelsen, dengan demikian, di dalam membangun teorinya, mencoba menempatkan dunia sollen (ought; seharusnya) sejajar dengan dunia sein (is; senyatanya). Hubungan antara yang yang "seharusnya" (sollen) dengan yang "senyatanya" (sein), bukanlah sekedar menunjukan relasi bahwa yang "senyatanya" berkesesuaian dengan yang "seharusnya", akan tetapi relasinya adalah bahwa: "sesuatu" yang disuatu ketika merupakan "senyatanya", dan dilain waktu merupakan yang "seharusnya".

26 Paulson, "Hans Kelsen's Earliest Legal Theory", The Modern Law Review Journal, Vol. 59 Issue 6, 2011, London: London School of Economics and Political Science Article first published online: 18 JAN 2011 | DOI: 10.1111/j.1468-2230.1996.tb02695.x, tersedia di web:

\section{Normativitas sollen merupakan kondisi logika transendental}

Sollen, meskipun termasuk dunia normatif (yang seharusnya), akan tetapi normativitas sollen, bukanlah alam transenden sebagaimana yang diklaim sebagai "ada" menurut hukum kodrat. Kebaradaan sollen bukanlah bersumber dari kekuasaan adi-kodrati diluar manusia, akan tetapi lebih manampakan dirinya sebagai sesuatu yang "ada" karena diandaikan ada. Sebagai pengandaian satu kondisi logiko-transendental bagi kognisi dalam ilmu, yaitu kondisi-kondisi pengalaman. Diandaikan sebagai "ada" yang tertinggi dan terakhir. "Ada" yang tertinggi dan terkhir inilah yang kemudian oleh kelsen dikonsepkan sebagai norma dasar (grund norm), karena bagi Kelsen hanya proposisi yang diberikan a priori oleh rasio, yang kebenarannya memerlukan pembenaran transendental, layak menjadi pengandaian transendental.

Sebagaimana dikemukan oleh Hans Kelsen: "bilamana Kant bertanya, "bagaimana tanpa merujuk pad metafisika, fakta-fakta yang dipersepsikan oleh indera kita bisa ditafsirkan sebagai fakta-fakta, sebagaimana yang dirumuskan oleh ilmu alam?" maka menurut Hans Kelsen akan sama pula dalam teori hukum murni, yang akan bertanya, "bagaimana, tanpa merujuk pada otoritas meta-hukum (seperti tuhan atau alam), makna subyektif dari fakta-fakta material tertentu, bisa ditafsirkan sebagai satu sistem norma-norma hukum sah secara obyektif, yang dapat digambarkan dalam proposisi-proposisi hukum?" 27 Berdasarkan pernyataan Kelsen di atas, dapatlah diketahuim bahwa, meskipun hukum dipandang secara normatif dalam terminologi ought, yang berbeda atau harus dibedakan secara tajam dari kenyataan empiris yang tercakup dalam terminologi "is", akan tetapi hukum, bukanlah bagian dari "hukum alam" yang tunduk pada prinsip-prinsip moral atas nama normativitas. ${ }^{28}$

\section{Asumsi Epistemologi}

http://onlinelibrary.wiley.com/doi/10.1111/j.14 682230.1996.tb02695.x/, hlm. 30

27 Hans Kelsen, 2007, Pure Theory of Law, ..., op. cit, hlm 202.

28 Hans Kelsen, 2008, Introduction to the Problem of Legal Theory, hlm, op. cit, hlm. 23-24. 


\section{Ilmu Hukum sebagai Ilmu Kognitif yang Bersifat Konstitutif}

Hans Kelsen menampilkan gagasan tentang fungsi konstitutif ilmu hukum kognitif. ${ }^{29}$ Menurut Kelsen, sebagaimana ilmu alam yang mempunyai tugas menciptakan "sistem hukum yang disatukan" dari "chaos" ("kekacauan”) prinsip-prinsip indrawi menjadi "cosmos" ("keteraturan") alam, sebagai sistem yang disatukan, melalui kognisi ilmu alam; maka ilmu hukum mempunyai tugas menciptakan "sistem hukum yang disatukan" dari berbagai macam norma individual dan norma umum ditetapkan oleh organ-organ hukum menjadi sistem yang padu suatu "tatanan" hukum melalui ilmu hukum. Ilmu hukum, karenanya, bertugas menciptakan "sistem hukum yang disatukan" dari "materi hukum yang kacau" seperti undang-undang, peraturan-peraturan, keputusan-keputusan pengadilan, tindakan-tindakan administratif, dan lain-lainnya. ${ }^{30}$

Berdasarkan pernyataan Kelsen di atas, dapatlah diketahui, bahwa tugas ilmu hukum bukanlah membentuk hukum (praktis), karena itu merupakan kewenangan yudikatif, legislatif dan eksekutif. Tugas utama ilmu hukum dengan menggunakan kognisi adalah mewujudkan struktur norma hukum yang "direkonstruksi" atau dirumuskan secara hipotesis. Penciptaaan yang dilakukan oleh ilmu hukum ini murni epistemologis, karena secara fundamental berbeda dari penciptaan obyek-obyeknya yang dilakukan oleh pekerja atau penciptaan hukum dari otoritas hukum yang diwakili oleh organ-organ hukum.

\section{Norma Hukum merupakan Satu Kesatuan Objek Kognisi yang Mandiri yang Bermakna (Otonom)}

Sebagai bagian dari upanya untuk menempatkan norma hukum sebagai objek yang mandiri, yang berbeda dengan norma yang ditetapkan oleh mazhab hukum kodrat, yang merujuk pada keabsahan moral, ataupun Madzhab empiris-positivisme yang merujuk pada realitas empiris, maka Kelsen mengajukan konsep norma dasar (grundnorm), yang diharapkan akan mempersatukan objek ilmu hukum, sehingga menjadi satu kesatuan objek kognisi ilmu hukum.

Kelsen, untuk membangun argumennya tersebut, merujuk pada dua hal. Pertama, konsep "Stufenbaulehre" (teori struktur hirarkis norma-norma) dari Adolf Rudolf Merkl, ${ }^{31}$ yang digunakan untuk menjelaskan sifat "dinamis" dan pemberian kekuasaan (pendelegasian wewenang) dari norma dasar; dan kedua, konsep transendental dari neo-Kantian, ${ }^{32}$ yang digunakan untuk menjelaskan pendasaran "transendental" dari teori hukum murni.

Berdasarkan konsep "Stufenbaulehre" dari Adolf Merkl, Kelsen mengajarkan bagaimana merekonstruksi beragam norma yang ada, menjadi satu kesatuan sistem (hukum), sehingga keseluruhannya dapat menjadi satu objek ilmu hukum yang mandiri, sedangkan untuk mencari sandaran filosofis sehingga norma yang tertinggi memperoleh dasar keabsahannya, Kelsen merujuk pada konsep transendental dari Immanuel Kant, terutama yang diajarkan oleh filosof dari kalangan Neo-Kantinian Heidelberg. Kelsen, untuk menjawab persoalan tersebut, mengawali dengan pertanyaan pokok khas kantianian (pertanyaan transendental): How is positive law possible as an object of cognition, as an object juridical science; and consequently, how is a juridical science possible? ${ }^{33}$ Terhadap pertanyaan transendental yang diajukannya tesebut, Kelsen memberikan jawaban bahwa: hukum positif mungkin sebagai objek kognisi ilmu hukum bila terdapat norma dasar hipotetis (hypothecical basic norm; pengandaian perlu bagi kognisi hu-kum positivistik). ${ }^{34}$

29 Hans Kelsen, 2007, Pure Theory of Law, ..., op. cit, hlm. 72.

30 Stanley L. Paulson, “Introduction” dalam Hans Kelsen, 2008, Introduction to the Problem of Legal Theory,..., op. cit, hlm. xxxvi...; Hans Kelsen, 2007, Pure Theory of Law, ..., op. cit, hlm. 72.

31 Stanley L. Paulson, “On The Implication of Kelsen's Doctrine of Hierarchical Structure", The Liverpool Law Review, Vol. XXV, 2010, Springer Netherlands, tersedia di web: http://www.springer.com/law/journal/, hlm. 49 62.

32 Boris Milosavljević, op. cit, hlm. 153.

33 Subrata Kumar Kundu, "Re-Visiting The Viability Of 'The Rule Of Recognition' And 'The Basic Norm' In Modern Legal Context”, Social Science Research Network (electric Journal), 2011, tersedia di web: http://papers.ssrn. com/sol3/papers.cfm?abstract_id=1866863, hlm. 6

34 Lihat Stanley L. Paulson, "Introduction" dalam Hans Kelsen, 2008, Introduction to the Problem of Legal Theory,..., op. cit, hlm. xxxv-xxxvi. 
Norma dasar merupakan formulasi pengandaian perlu dari semua kognisi hukum. Norma dasar inilah yang akan berperan memberi kesadaran, mengarahkan serta mengklarifikasi, para ilmuan yang mengkognisi materi hukum, agar memahami data yang terberi bukan sebagai fakta empiris atau sebagai bagian dari norma-norma moral yang bersumber dari hukum kodrat, melainkan sebagai norma hukum. ${ }^{35}$

Norma dasar ini dimaksudkan sebagi sebuah keharusan konseptual dalam bentuk norma tertinggi yang "diandaikan" sebagai sah. Keabsahan norma tertinggi ini diterima begitu saja sebagai pengandaian pengetahuan hukum. Norma dasar ini menurut Kelsen merupakan sebuah norma fundamental dan hipotesis yang bukan merupakan bagian dari hukum positif. Teori hukum hanya menentukan bahwa hanya jika norma dasar diandaikan dalam proses yang mengantarkan tindakan menetapkan konstitusi; maka konstitusi dapat diakui sebagai norma dasar yang mengikat dan tindakan yang memunculkan konstitusi dapat diakui sebagai tindakan hukum. Kelsen, di sini meletakkan karakter hipotesis dari norma dasar itu. Akan tetapi meskipun merupakan norma hipotesis, menurut Kelsen norma dasar tersebut tetap merupakan sebuah norma dasar awal, sehingga dianggap sebagai norma pemberi otoritas, juridico-logical constitution (konstitusi yuridis logis), yang mendasari keabsahan hukum positif.

Norma dasar merupakan puncak kewenangan tertinggi dalam menetapkan keabsahan dari norma-norma hukum sekaligus menjamin bahwa norma-norma yang berasal dari satu otoritas tertinggi tersebut dibuat dan ditetapkan dengan cara yang telah ditetapkan. Dengan demikian norma dasar bukan hanya memberi dasar kesatuan formal (yaitu sebagai kriteria tunggal di mana keanggotaan norma-norma hukum, dan karena itu identitas dari sistem hukum sebagai keseluruhan, bisa ditetapkan), akan tetapi juga memberi dasar kesatuan material, dalam hal ini norma dasar selain memastikan bahwa hukum merupakan sesuatu yang ditetapkan oleh sebuah otoritas, juga memastikan bahwa apa yang ditetapkan oleh otoritas itu sesuai dengan satu kesatuan yang bermakna.

Hans Kelsen, melalui pengandaian norma dasar ini berupaya menjembatani kesenjangan antara ought dan is; sehingga hukum dapat dipahami sebagai satu kesatuan sistem yang terdiri dari beragam norma hukum yang bermakna. Dengan mendasarkan pada norma dasar sebagai dasar hipotesisnya, yaitu suatu pengandaian bahwa jika norma dasar itu sah, maka seluruh sistem hukum yang merujuk pada norma dasar itu juga sah, maka makna ought, yang semula menjadi kandungan norma dasar, didelegasikan kepada semua norma-norma yang berada di tingkat bawahnya, sehingga keseluruham norma yang tersusun sebagai satu kesatuan sistem tersebut, dapat dijadikan dasar untuk memberikan makna hukum terhadap beragam data-data empiris yang ada. Hal ini dapat tejadi, karena melalui makna ought inilah, kondisi hukum dihubungkan dengan konsekuensi, dalam norma hukum yang direkonstruksi, sehingga berbagai data empiris tersebut memiliki makan hukum (bersifat normativitas), di mana keseluruhan makna hukum yang terbentuk tersebut pada akhirnya dapat dikembalikan lagi kepada sumber awalnya yaitu norma dasar. Beragam materi hukum yang memperoleh kualitas ought, (dan terbentuk sebagai hukum positif) dapat dipahami sebagai keseluruhan yang bermakna karena diterapkannya prinsip non-kontradiksi dalam ranah sollen (yaitu langsung terhadap norma). Demikian cara norma dasar memberi makna normatif (ought) terhadap semua fakta material yang menyusun sistem hukum itu. Melalui norma dasar inilah seluruh data empiris yang diberikan bisa ditafsirkan sebagai hukum yaitu, sebagai sebuah sistem norma-norma hukum.

Penempatan makna ought sebagai media transmisi dari seluruh materi hukum yang akan direkonstruksi sebagai satu kesatuan sistem,di dasarkan pada penafsiran Kelsen terhadap ajaran agama. Menurut Hans Kelsen, alasan keberlakuan sebuah norma bukanlah karena Tuhan atau Putra-Nya mengeluarkan norma tertentu pada

35 Hans Kelsen, 2008, Introduction to the Problem of Legal Theory, ..., hlm. 58. 
waktu tertentu, melainkan karena kualitas dari apa yang diucapkannya, yaitu berupa norma yang secara halus mengandaikan bahwa: kita "seharusnya" mematuhi perintah Tuhan atau PutraNya. Dengan demikian keberlakuan sebuah norma bukanlah didasarkan pada ada tidaknya otoritas (baik manusia maupun Tuhan), melainkan pernyataan "seharusnya" yang menegaskan keberlakuan norma yang lebih tinggi, dan sekaligus menegaskan keberlakuan norma yang lebih rendah". 36

Norma yang keabsahannya dinyatakan dengan pernyataan "seharusnya", mencakup sebuah pengandaian bahwa norma itu berasal dari sebuah otoritas, yakni dari seseorang yang berkompeten untuk menciptakan norma yang absah; norma ini memberikan "otoritas" penciptaan norma kepada pribadi pencipta norma itu. Fakta bahwa seseorang memerintahkan sesuatu bukanlah alasan untuk menganggap perintah itu sebagai norma yang absah, yang mengikat individu yang dituju norma itu. Hanya otoritas yang berkompeten yang bisa menciptakan norma yang absah; dan kompetensi itu hanya bisa didasarkan pada norma yang memberi kuasa atas disahkannya norma. Otoritas yang diberi kuasa untuk membuat norma tunduk kepada norma itu seperti halnya individu juga tunduk kepada norma yang dibuat oleh otoritas itu.

\section{Norma Hukum yang Direkonstruksi Terbentuk dari Relasi antara Fakta-fakta Material yang Bersifat Non-Kausal \& Non-Metafisikal (Asumsi Imputasi)}

Sebagai upayanya untuk melepaskan objek ilmu hukum dari klaim sosiologis yang menggunakan metode ilmu kausal untuk mengasumsikan hukum sebagai bagian dari alam, dan dari pernyataan-pernyataan teori hukum alam yang memasukan ilmu hukum kedalam bidang postulat etika politik, Kelsen menampilkan kategori ought melalui fungsi imputasi, sebagai sebuah katagori normatif spesifik yang otonom. Ought sebagai

36 Hans Kelsen, 2007, Pure Theory of Law, ..., hlm. 194.

37 Hans Kelsen, 2008, Introduction to the Problem of Legal Theory, ..., op. cit, hlm. 24.

38 Jörg Kammerhofer, Friedrich-Alexander Universität, Erlangen-Nürnberg , "The Benefits of the Pure theory of sebuah katagori transendental, dimunculkan sebagai upaya untuk mengkonstruksi relasi antara fakta-fakta material, sehingga hubungan yang ada, terdeskripsi sebagai sebuah hubungan yang khas, yang hanya terjadi dalam sistem hukum, yang kemudian dapat dibedakan dengan relasi kausal dalam ilmu alam. Bila didalam ilmu alam, katagori must" (harus) difungsikan untuk mengungkapkan relasi kausalitas, sebagaimana hukum-hukum dari alam menyatakatan: If $A$ is, then $B$ must be. (Jika A terjadi, maka B pasti terjadi). Maka didalam ilmu hukum (hukum positif), katagori ought difungsikan untuk mengungkapkan relasi imputasi, sebagaimana yang dinyatakan dalam ilmu hukum: If $A$ is, then $B$ ought to be, (jika $A$ terjadi maka $B$ seharusnya terjadi). Kategori ought, dengan demikian menampilkan dirinya sebagai sebuah kategori a priori relatif yang berfungsi untuk memahami relasi antara data (hukum) empiris. Katagori ought, sebagai katagori spesifik dan otonom, sangat diperlukan, agar ilmu hukum, dapat tampil sebagai sebuah disiplin ilmu, yang dapat mengungkapkan relasi antara fakta-fakta material yang bersifat nonkausal dan non-metafisikal (non-meta hukum).

Kelsen berpendapat bahwa dengan imputasi memungkinkan satu fakta material yang bisa dicerap oleh indera dihubungkan dengan fakta material lainnya, bukan secara kausal, tetapi secara normatif, dengan memberikan "interpretasi normatif" terhadap fakta-fakta material ini. ${ }^{37}$ Upaya yang dilakukan Kelsen tersebut, secara epistemologis tertambat pada Copernican turn sebagai inti epistemologis dari filsafat transendental Kant. ${ }^{38}$ Immanuel Kant, melalui Copernican turn ini, mengajarkan bahwa semua pengetahuan mengenai objek-objek tergantung kepada kondisi-kondisi formal dan konstitutif dari kognisi teoretis. Jadi, kognisi tidak ditentukan oleh obyek-obyek yang ada secara terlepas dari kognisi itu. Sebaliknya, obyek ada hanya dalam (dan ditentukan oleh) bentuk-bentuk (kategori) transendental dari kognisi itu sendiri. Dalam kon-

law for International lawyers, or: What use is Kelsenian theory", Internatlonal legal theory, Vol. 12 Fall 2006, American Society of international law, United State: University of Baltimore, hlm. 22. 
teks yang demikianlah maka Kelsen kemudian berpendapat, ought sebagai katagori transendental, ${ }^{39}$ merupakan katagori yang berasal dari rasio, dan diterapkan untuk mengkonstitusikan norma sebagai obyek kognisi. Oleh karena itu ought ditempatkan sederajat dengan kategorikategori pemahaman, yang mengkonstitusi kognisi sebagai pengalaman mengenai objek-objek dalam alam. Menurut kelsen prinsip imputasi sebagai sebuah kategori dalam ilmu hukum kognitif sebanding dengan prinsip kausalitas sebagai kategori ilmu alam. ${ }^{40}$

\section{Asumsi Aksiologi}

Setiap Ilmu Harus Memiliki Objeknya Sendiri dan Objek Ilmu Hukum adalah Norma yang Direkonstruksi.

Kelsen, untuk dapat menyusun dan memberi landasan filosofis yang kokoh pada upayanya menjadikan hukum sebagai satu obyek kognisi ilmiah (menjamin otonomi hukum sebagai objek ilmiah) mendasarkan pemurnian obyek dari teori hukum, pada: doktrin konstruktivisme, ${ }^{41}$ yang ditambatkan pada doktrin methodological dualism. Kelsen, melalui konstruktivisme, berupaya "memurnikan" konstruksi-konstruksi pokok dalam ilmu hukum tradisional Jerman. Kelsen, untuk itu memperkenalkan konsep normatif atau normativity thesis (tesis normativitas), sebagai sebuah konsep terkonstruksi, guna menggantikan konsep "psikis", serta sebagai pengganti facticity thesis, dua aspek yang menjadi rujukan dalam positivisme hukum tradisional.

Melalui doktrin dualisme metodologis yang diperluas, ${ }^{42}$ konsep "kemurnian," Kelsen, dilakukan dengan cara menghindari terjadinya penyatuan atau kombinasi yang tidak sah dari berbagai metode kognisi yang berbeda. Sebagaimana yang terlihat dalam ilmu hukum tradisional, yang melakukan transformasi metode kognitif dari alam obyektif (realitas kodrati) sebagai proses-proses dan kejadian-kejadian natural, menuju alam konseptual.

39 Hans Kelsen, 2008, Introduction to the Problem of Legal Theory, ..., Op. Cit, hlm. 23-25.

40 Ibid, hlm. 23.

41 Lihat lebih lanjut Sylvie Delacroix, 2004, Hart's and Kelsen's Concepts of Normativity Contrasted, Ratio Juris
Kelsen, dengan mendasarkan pada doktrin methodological dualism, melakukan pemisahan secara tajam antara ought dengan is, guna melakukan pembedaan secara ketat dan komprehensif dari dua dunia yang sangat berbeda, yaitu antara dunia ought dan dunia is, seperti yang dilakukan dan dibela oleh kaum neo-Kantinian Heidelberg. Kelsen, dalam hal ini benar-benar berupaya memisahkan dengan tegas kognisi normatif dengan kognisi kausal (sebab-akibat). Selain daripada itu, dengan mengacu pada doktrin dualisme metodologis yang diperluas ini pula, Kelsen melakukan pemurnian ilmu hukum dari elemen-elemen naturalisme dan psikologisme.

\section{Norma dasar memiliki kualitas yang sama dan sederajat dengan hukum alam \\ Penolakan Kelsen terhadap teori Imaji dan} ide-ide platonik, mengantarkan pada pendapatnya bahwa, kognisi rasional tidak dapat mencapai keadilan yang bersifat absolut, dan dengan demikian maka teori hukum murni tidak bisa menjadikan keadilan yang mengandung nilai mutlak, sebagai muatanya, karena Ilmu kognitif akan menjadi "kosong" bila digunakan untuk menentukan nilai mutlak yang ditandai oleh keharusan.

Hukum positif (sebagai tatanan yang memaksa) sebagaimana hukum alam (sebagai tatanan yang tidak memaksa), sama-sama merupakan tatatan dan sistem norma yang hanya bisa diekspresikan oleh yang seharusnya (ought). Keduanya sama-sama tidak mengikuti kaidah keharusan dalam pengertian kausal, namun kaidah lain yang "seharusnya" dalam pengertian normativitas. Normativitas harus dipahami dalam pengertian yang sepenuhnya relatif dan formal. Pertentangan antara realitas dan norma (senyatanya dengan seharusnya), harus dipahami sebagai pertentangan relatif. Karenanya dalam pertentangan dengan hukum alam, hukum positif muncul sebagai sesuatu yang artifisial, yakni sesuatu yang diciptakan oleh tindakan dari kehen-

Journal, Vol. 17 Issue 4, December 2004, Italy: University of Bologna, hlm. 514

42 Ibid, hlm. 518 
dak manusia empiris yang terjadi dalam wilayah ada (being), yakni dalam wilayah tindakan-tindakan aktual. Oleh karenanya ia tampil sebagai sebuah realitas yang dipertentangankan dengan hukum alam sebagai sebuah nilai. Munculnya klaim bahwa sebuah hukum positif itu baik dan buruk, kemungkinan berasal dari relasi ini. Sebuah hukum positif tertentu, hukum dari komunitas historis tertentu, baru mengemuka sebagai sesuatu yang baik atau buruk, "adil" atau "tidak adil", setelah dinilai melalu standar hukum alam yang validitasnya diterima begitu saja.

\section{Penutup}

Simpulan

Ada beberapa simpulan yang diberikan atas pembahasan di atas berdasarkan teori hukum murni. Pertama, secara ontologis objek dari ilmu hukum adalah norma hukum, yang berkarakter: norma hukum sebagai makna tindakan berkehendak; dan norma hukum sebagai norma moral relatif yang berkarakter normatif. Kedua, secara epistemologi, ilmu hukum berfungsi untuk mengetahui hukum yang berlaku terhadap suatu perilaku/peristiwa kongkrit tertentu (melalui teori struktur hierarkis/stufenbaulehre) dan menjelaskan hukum yang diberlakukan terhadap perilaku/peristiwa faktual-konkrit (melalui prinsip imputasi. Ketiga, secara aksiologis, ilmu hukum, bertujuan untuk membebaskan/memurnikan ilmu hukum dari anasir-anasir asing dan norma hukum ditujukan untuk mewujudkan keadilan relatif (kepastian hukum)

Ada beberapa asumsi-asumsi dasar teori hukum murni. Pertama, asumsi tentang manusia. Manusia pendukung teori hukum murni adalah manusia ilmiah-kritis, dengan karakter: manusia quasi-transendental dan manusia aurea aetas. Kedua, asumsi dasar tentang aspek ontologis. Objek ilmu hukum sebagaimana ditetapkan dalam teori hukum murni, didasarkan pada asumsi: realitas adalah Realitas empiris yang didukung oleh realitas transendental; realitas terbagi dua: yaitu realitas seharusnya (sollen; ought) dan senyatanya (sein; is), dan merupakan realitas yang sedarajat; Normativitas sollen merupakan kondisi logiko transendental. Ketiga, asumsi Epistemologi. Fungsi ilmu hukum sebagaimana ditetapkan dalam teori hukum murni, didasarkan pada asumsi: Ilmu hukum sebagai ilmu kognitif yang bersifat konstitutif; norma hukum merupakan satu kesatuan objek kognisi yang mandiri yang bermakna (otonom); norma hukum yang direkonstruksi terbentuk dari relasi antara fakta-fakta material yang bersifat non-kausal dan non-metafisikal. Keempat, asumsi aksiologi. Tujuan ilmu hukum sebagaimana ditetapkan dalam teori hukum murni, didasarkan pada asumsi: setiap ilmu harus memiliki objeknya sendiri, dan objek ilmu hukum adalah norma yang direkonstruksi; norma dasar memiliki kualitas yang sama dan sederajat dengan hukum alam.

\section{Daftar Pustaka}

Delacroix, Sylvie. "Hart's and Kelsen's Concepts of Normativity Contrasted". Ratio Juris Journal. Vol. 17 Issue 4. December 2004. Italy: University of Bologna;

Ebenstein, William. "What Is Justice? Justice. Law by Hans Kelsen". Journals American Political Science Review. Vol. 52 Issue 02. 2013. Published online by Cambridge University Press 02 Sep 2013;

Frew, Kendra. "Hans Kelsen's Theory and The Key to His Normativist Dimension". The Western Australian Jurist Journal. Vol. 4 2013. Murdoch University: Western Australian Legal Theory Association (WALTA);

García, Mónica -Salmones Rovir. 2013. The Politics Of Interest In International Law. New York University School of Law: The Jean Monnet Center for international and Regional Economic Law and Justice. http: //www.JeanMonnetPro-gram.org;

Ibrahim, Sidik. "Paradigma Islam dan Transformasi Sosial (Studi Pemikiran Kuntowijoyo)". Hunafa: Jurnal Studia Islamika. Vol. 2 No 3 2005. Palu: Institut Agama Islam Negeri (IAIN) Palu Sulawesi Tengah;

Kammerhofer, Jörg. Friedrich-Alexander Universität. Erlangen-Nürnberg. "The Benefits of the Pure theory of law for Interna-tional lawyers. or: What use is Kelsenian theory." International legal theory. Vol. 12, Fall 2006. American Society of inter-national law. United State: University of Baltimore;

Kelsen, Hans. 2007. Pure Theory of Law: Legality and Legitimacy. transltaed by Lars Vinx. New York: Oxford University Press; 
2008. Introduction to the Problem of Legal Theory. a translation of the Reine Rechtslehre or Pure Theory of Law by Bonnie Litschewski Paulson and Stanley L. Paulson. reprinted Oxford University Press: Clarendon Press;

2011. General Theory of Law and State. Appendix: The Epistemological (Metaphysical) and Psychological Foundation. Translated by Anders Wedberg. United States: Imprint Lawbook Exchange;

Kletzer, Christoph. “Absolute Positivism”. Netherlands Journal of Legal Philosophy. Aflevering 2-2013. tersedia di web: http:// www.bjutijdschriften.nl/tijdschrift/recht sfilosofieentheorie/2013/2/NJLP_22130713_2013_042_002_002;

Kundu, Subrata Kumar. 2011. "Re-Visiting The Viability Of 'The Rule Of Recognition' And 'The Basic Norm' In Modern Legal Context". Social Science Research Network (electric Journal). http: / / papers.ssrn.com / sol3/papers.cfm?abstract_id=1866863;

Milosavljević, Boris. 2013. “An Early Critique of Kelsen'S Pure Theory Of Law: Slobodan Jovanović On The Basic Norm And Prima-cy Of Inetrnational Law". Belgrade Law Review. Year LXI. No. 3. 2013. Serbia: Faculty of Law - University of Belgrade;

Paulson, Stanley L. “How Merkl's Stufenbaulehre Informs Kelsen's Concept. Revus". Journal for Constitutional Theory and Philosophy of Law. Vol. 21. 2013. Klub Revus: Center za raziskovanje evropske ustavnosti in demokracije. Tersedia di web: http:// revus.revues.org/ 2727;

Paulson, Stanley L. “The Neo-Kantian Dimension of Kelsen's Pure Theory of Law". Oxford Journal of Legal Studies. Vol. 12. No. 3. Autumn2005;

Paulson. Hans Kelsen's Earliest Legal Theory. The Modern Law Review Journal. Vol. 59
Issue 6. 2011. London: London School of Economics and Political Science Article first published online: 18 JAN 2011 | DOI: 10.1111/j.1468-2230.1996.tb02695.x.

Tersedia di web: http://onlinelibrary. wiley.com/doi/10.1111/j.1468-2230. 1996.tb02695.x/;

Popovic, Milijan. "Methodological Models of The General Theory of Law". facta Universitates. series: Law and Politics Jurnal. Vol. 1 No. 6. 2002;

Putra, Heddy Shri Ahimsa. "Fenomenologi Agama: Pendekatan Fenomenologi untuk Memahami Agama". Walisongo Walisongo; Jurnal Penelitian Sosial Keagamaan. Vol. 20. No. 2 November 2012. Semarang: Lembaga Penelitian (LEMLIT) IAIN Walisongo Semarang;

Putra, Heddy Shri Ahimsa. 2011. Paradigma. Epistemologi dan Etnografi dalam Antropologi. Makalah disampaikan dalam ceramah "Perkembangan Teori dan Metode Antropologi". Diselenggarakan oleh Departemen Antropologi. Fakultas Ilmu Sosial dan Ilmu Politik. Universitas Airlangga. di Surabaya. 6-7 Mei 2011;

Stanley L. Paulson. "On The Implication of Kelsen's Doctrine of Hierarchical Structure". The Liverpool Law Review. Vol. XXV. 2010. Springer Netherlands. Tersedia di web: http://www.springer.com/law/ journal/;

Wahyu, Bambang. "Filsafat Ekonomi Islam: Rasionalitas Dan Religiusitas Ekonomi". Jurnal Ekonomi Islam Al-Infaq. Vol. 1 No. 1. September 2010. Bogor: Program Studi Ekonomi Islam Fakultas Agama Islam Universitas Ibn Khaldun Bogor;

Wignjosoebroto, Soetandyo. "Memperbincangkan 'Hukum' dari Perspektif Filsafat: Paradigma Hukum dan Pergeserannya dalam Sejarah". Jurnal Digest Epistema. Vol 1. Tahun 2011. Jakarta: Epistema Institut. 